\title{
Hubungan Faktor Bimbingan Praktik terhadap Pencapaian Kompetensi Keterampilan Asuhan Kehamilan pada Praktek Klinik
}

\section{Ria Tri Harini*1, Dwi Rusiawati²}

1,2 Prodi D 3 Kebidanan, Undiksha, Bali

\section{A R T I C L E I N F O}

Article history:

Received 19 February 2018

Received in revised form

10 March 2018

Accepted 12 April 2018

Available online 25 May

2018

Kata Kunci:

Bimbingan Praktek;

Kompetensi Keterampilan.

Keywords:

Practice Guidance; Skill

Competence

\begin{abstract}
A B S T R A K
Penelitian ini bertujuan untuk mengidentifikasi dan mendeskripsikan hubungan faktor bimbingan praktek terhadap pencapaian kompetensi keterampilan asuhan kehamilan pada mahasiswa.Penelitian ini menggunakan pendekatan ex post facto, dengan metode analisis regresi. Responden dalam penelitian ini adalah seluruh mahasiswa semester $\mathrm{V}$ Prodi D 3 Kebidanan Undiksha berjumlah 80 orang. Penelitian ini melibatkan variabel bebas yaitu Bimbingan Praktek (X), dan variabel terikat yaitu Pencapaian Kompetensi Keterampilan (Y). Alat ukur variabel bebas adalah kuisioner dengan skala Likert yang telah diuji validitas dan reliabilitasnya. Berdasarkan hasil perhitungan analisis regresi sederhana diperoleh : $F_{\text {reg }}=18,391>F_{\text {tab }}=3,96(\alpha=0,05)$ adalah signifikan dan linier, $r_{\text {hit }}=0,386>r_{\text {tab }}=0,220(\alpha=0,05)$ adalah signifikan, kontribusi $=22,0 \%$ dan $\mathrm{SE}=7,50 \%$. Dengan demikian, dapat disimpulkan ada hubungan yang signifikan antara faktor bimbingan praktek dengan pencapaian kompetensi keterampilan asuhan kehamilan mahasiswa Prodi D 3 Kebidanan Undiksha.Bertolak dari hasil penelitian tersebut dapat direkomendasikan bahwa meskipun pencapaian kompetensi keterampilan mahasiswa sudah baik namun perlu dilakukan peningkatan secara kontinyu, dengan jalan melengkapi sarana dan peralatan, serta meningkatkan proses pembelajaran praktik.
\end{abstract}

\section{A B S T R A C T}

This study aimed at identifying and describing the correlation between the factor of practice guidance and skill competence in pregnancy care among the students of Prodi D 3 Kebidanan Undiksha. This study used an ex post facto approach, by using regression analysis. The respondents in this study are all of students of Prodi D 3 Kebidanan Undiksha in the fifth semester numbering 80 persons. The variables of the study consisted of independent variable : Practice Guidance $(X)$ and dependent variable : Skill Competence Achievement $(\mathrm{Y})$. The instrument used for the independent variable was questionnaire with Likert's scale that has been tested for its validity and reliability. On the basis of the result of simple regression analysis it was found that $F_{\text {reg }}=18.391>F_{\text {tab }}=3.96(\alpha=0.05)$ was significant and linear, $r_{\text {observed }}$ $=0.386>r_{\text {tab }}=0.220(\alpha=0.05)$ was significant, the contribution $=22.0 \%$ and Effective Contribution $=$ $7.50 \%$. Hence, it can be concluded that there is a significant correlation between practice guidance and skill competence achievement in pregnancy care competence among the students of Prodi D 3 Kebidanan Undiksha. From the results it can be recommended that although the students' skill competence achievement is good continuous improvement efforts still need to be made by providing complete infrastructure and equipment, and improving practice in the teaching and learning process.

\footnotetext{
* Corresponding author.

E-mail addresses: riatriharini@gmail.com (Ria Tri Harini )
} 


\section{Pendahuluan}

Sebagai sebuah profesi yang diakui dunia, bidan dituntut untuk bertanggung jawab dan mempertanggungjawabkan prakteknya dalam memberikan pelayanan dan atau asuhan secara profesional. Profesionalisme dalam pelaksanaan asuhan Kebidanan yang dilakukan ditentukan oleh kemampuan seorang bidan dalam menerapkan ilmu dan keterampilannya sesuai kewenangan yang diberikan pada profesinya. Dewasa ini, bidan memiliki kewenangan yang cukup luas, sebagaimana diatur dalam Permenkes Nomor 900 tahun 2002 (Menkes RI, 2002).

Menyikapi diperluasnya kewenangan bidan tersebut, serta untuk menjawab tuntutan masyarakat akan peningkatan mutu pelayanan Kebidanan sesuai perkembangan ilmu, tehnologi dan psikososialbudaya, bidan dituntut untuk secara terus menerus meningkatkan pengetahuan dan keterampilannya melalui pendidikan non formal, formal, maupun informal. Untuk meningkatkan pengetahuan dan keterampilan melalui pendidikan formal tersebut disusunlah kurikulum D 3 Kebidanan yang memberikan situasi dan kondisi belajar yang representatif bagi mahasiswa untuk menguasai dan mendalami ilmu dan kiat Kebidanan. Karena dengan menguasai ilmu dan kiat Kebidanan secara benar dapat menumbuhkan dan membina sikap mahasiswa dalam melaksanakan asuhan Kebidanan secara profesional.

Prodi D 3 Kebidanan Undiksha sebagai salah satu penyelenggara pendidikan tenaga kesehatan telah berupaya untuk memenuhi tuntutan lapangan kerja terhadap kualitas lulusan yang dihasilkan dengan menyelenggarakan proses pendidikan yang mengacu pada kurikulum berbasis kompetensi. Proses pendidikan tersebut dilaksanakan melalui dua kegiatan pokok yaitu kegiatan pembelajaran teoritik dan kegiatan pembelajaran praktika sebagai upaya untuk meningkatkan kompetensi pengetahuan, sikap dan keterampilan. Proses belajar yang dilakukan akan menghasilkan perubahan sebagai wujud kompetensi yang dicapai.

Kompetensi ini menjadi bagian dari proses pembelajaran praktika pada Prodi D 3 Kebidanan Undiksha yang bertujuan untuk meningkatkan kemampuan mahasiswa dalam memberikan asuhan Kebidanan pada klien termasuk asuhan kehamilan. Kemampuan mahasiswa untuk mencapai kompetensi keterampilan dalam melaksanakan asuhan kehamilan dapat terlihat dari nilai-nilai yang diperoleh. Dalam empat tahun belakangan, yakni tahun 2015 nilai rata-rata dari pelaksanaan keterampilan asuhan kehamilan yang diperoleh mahasiswa adalah 74 dengan katagori BAIK, tahun 2017 nilai rata-rata keterampilan melaksanakan asuhan kehamilan yang bisa diperoleh mahasiswa adalah 76 dengan katagori BAIK. Sementara itu, berdasarkan hasil evaluasi keterampilan asuhan kehamilan yang dilaksanakan di kampus D 3 Kebidanan Undiksha maupun nilai praktek klinik mahasiswa, rata-rata nilai keterampilan asuhan kehamilan yang diperoleh mahasiswa adalah 78 dengan katagori BAIK. Dari data tersebut dapat terlihat bahwa walaupun ada kenaikan namun sangat lambat.

Pencapaian kompetensi tersebut tidak lepas dari bimbingan yang diberikan selama proses pembelajaran. Melalui bimbingan keterampilan praktek untuk mencapai kompetensi, mahasiswa dapat menerapkan teori-teori yang didapat selama pembelajaran teoritik ke dalam tindakan klinis yang tepat sebagai persiapan dalam menghadapi situasi nyata di lapangan kerja. Selama ini bimbingan yang diberikan kepada mahasiswa Prodi D 3 Kebidanan Undiksha dilakukan oleh pembimbing baik dari intitusi pendidikan dan pembimbing klinik di lahan praktek, dengan memberikan pengarahan untuk mencapai kinerja tertentu. Sebelum melaksanakan praktek klinik di lahan praktek, mahasiswa mendapatkan bimbingan penuh dari pembimbing di kampus dan saat melaksanakan praktek, mahasiswa mendapat bimbingan dari para pembimbing di klinik. Keberadaan pembimbing dapat mempengaruhi perkembangan kemampuan kognitif, afektif dan keterampilan peserta didik. Pembimbing dapat menjadi model bagi mahasiswa untuk belajar berperilaku efektif terhadap diri sendiri atau saat berinteraksi dengan orang lain (klien). Selain peran dan gaya kepemimpinan, hubungan terapeutik yang dilakukan pembimbing dapat memfasilitasi perkembangan peserta didik dan keberhasilan proses pembelajaran. Sayangnya, terkadang mahasiswa jarang merasakan hubungan yang efektif dengan pembimbing. Kurangnya kesiapan mahasiswa dalam mengikuti proses belajar dapat menjadi konflik dengan pembimbing yang kemudian menimbulkan ansietas bagi mereka. Berdasarkan informasi yang berhasil digali dari mahasiswa, diketahui bahwa mahasiswa selalu merasa tegang saat menghadapi pembimbing. Alit (2002) mengemukakan bahwa pembimbing harus dapat mengembangkan hubungan, menciptakan lingkungan atau suasana belajar yang kondusif agar tumbuh self motivation, kematangan pribadi dan pembelajaran yang bermakna pada peserta didik dapat tercapai. Alit (2001 : 10) mengemukakan beberapa peran pembimbing klinik yang diharapkan dapat membantu meningkatkan kemampuan kognitif, afektif dan keterampilan yang diharapkan yakni sebagai model, pengamat, peserta dan nara sumber. Situasi yang memfasilitasi proses pembelajaran klinik adalah kesiapan peserta didik dan pembimbing klinik yang memberi dorongan emosional dengan menciptakan suasana yang kondusif dan tidak mengancam. Beberapa karakeristik pembimbing yang diharapkan adalah: humoris, respek (memperhatikan dan menghargai), dan antusias. 
Alit juga mengemukakan bahwa fokus sentral staf pengajar/pembimbing adalah mengembangkan hubungan, menciptakan suasana lingkungan yang kondusif agar self motivation, kematangan kepribadian, dan pembelajaran yang bermakna dari peserta didik dapat tercapai. Hubungan antar pembimbing dan peserta didik yang terjalin melalui komunikasi merupakan unsur yang juga penting dalam aktivitas belajar dan menjadi bagian yang selalu ada dalam proses pembelajaran.

\section{Metode}

Penelitian ini adalah penelitian terapan, menggunakan pendekatan ex post facto. Menurut tingkat eksplanasinya, penelitian ini tergolong dalam penelitian asosiatif, yaitu menganalisa determinasi satu variabel bebas terhadap satu variabel terikat. Penelitian ini termasuk dalam penelitian kuantitatif.

Populasi yang digunakan dalam penelitian ini adalah mahasiswa Prodi D 3 Kebidanan Undiksha semester V berjumlah 80 orang, dengan dasar pertimbangan bahwa mahasiswa pada semester ini telah mendapatkan mata kuliah asuhan kehamilan dan telah menjalani proses bimbingan praktek untuk mata kuliah tersebut baik di laboratorium institusi pendidikan maupun di lahan praktek. Tehnik sampling yang digunakan dalam penelitian ini adalah total sampling. Instrumen yang digunakan dalam penelitian ini berupa kuisioner bimbingan praktek, dan format penilaian untuk menilai kompetensi keterampilan asuhan kehamilan.

Selanjutnya data yang diperoleh dianalisis dengan menggunakan statistik deskriptif dan inferensial, yaitu Bivariate Analysis Variance.

\section{Hasil dan pembahasan}

Berdasarkan hasil analisis yang dibuat, terlihat bahwa secara normatif pencapaian keterampilan praktik mahasiswa Prodi D 3 Kebidanan Undiksha berada pada katagori baik, dengan rata-rata nilai sebesar 75,088, dan simpangan baku sebesar 9,066. Pencapaian kompetensi keterampilan dalam penelitian ini diartikan sebagai gambaran hasil belajar mahasiswa dalam melaksanakan asuhan kehamilan kepada klien, kemampuan melaksanakan keterampilan ini didasari oleh rasa tanggung jawab profesional yang dimiliki.

Sebagai seorang calon bidan profesional, mahasiswa Prodi D 3 Kebidanan Undiksha dituntut untuk menguasai setiap teknik keterampilan dalam melaksanakan asuhan kebidanan kepada klien, termasuk dalam melaksanakan asuhan kehamilan. Untuk menilai cakap tidaknya mahasiswa dalam melaksanakan keterampilan, dilakukan evaluasi hasil belajar pada akhir semester. Evaluasi ini dilakukan sesuai dengan prosedur yang ditetapkan dimana mahasiswa sebelumnya telah dibimbing dengan menggunakan penuntun belajar asuhan kehamilan. Penuntun belajar tersebut berisi langkah-langkah kegiatan pelaksanaan asuhan kehamilan yang sesuai dengan prosedur tetap yang diterapkan di lahan praktek. Berbekal penuntun belajar itu mahasiswa melatih keterampilannya dalam melaksanakan asuhan kehamilan. Latihan awal dilakukan di laboratorium klinik di kampus Prodi D 3 Kebidanan, sampai mahasiswa dianggap mampu untuk kemudian dilanjutkan dengan latihan dibeberapa Praktek Bidan Swasta di Singaraja yang telah memiliki kontrak kerjasama dengan institusi pendidikan. Setelah latihan yang dilakukan dianggap cukup dan mahasiswa telah siap untuk penilaian kompetensi keterampilan, maka kemudian dilakukan evaluasi keterampilan.

Evaluasi untuk menilai pencapaian kompetensi keterampilan yang dimiliki mahasiswa termasuk keterampilan dalam melaksanakan asuhan kehamilan dilakukan di kampus Prodi D 3 Kebidanan Undiksha dan juga di ruang kebidanan di Rumah Sakit - Rumah Sakit Pemerintah maupun Puskesmas yang digunakan sebagai lahan praktik.

Menurut Hornby (dalam Syamsudin, 2006) kompetensi pada dasarnya menunjukkan kemampuan dan kecakapan seseorang untuk mengerjakan suatu pekerjaan yang diekspresikan melalui kinerja rasional untuk mencapai tujuan secara memuaskan berdasarkan kondisi. Kompetensi keterampilan praktik dalam penelitian ini diartikan sebagai kemampuan mahasiswa dalam melaksanakan asuhan kebidanan dengan menunjukkan karakteristik utama antara lain kompetensi profesional dan sosial. Pada penelitian ini pencapaian kompetensi praktik mahasiswa berada pada katagori baik, dimana dapat 
diperolehnya nilai tersebut tidak lepas dari proses bimbingan yang diberikan oleh pembimbing baik dari institusi pendidikan maupun lahan praktik.

Dari hasil analisis data Bimbingan Praktek, terlihat bahwa bimbingan praktek secara normatif berada pada katagori cukup, dengan nilai rata-rata sebesar 99,725 dan simpangan baku sebesar 10,156.. Bimbingan praktek diberikan kepada mahasiswa melalui pengalaman belajar praktika yang dilaksanakan baik di laboratorium klinik maupun lahan praktik. Dalam pelaksanaan pembelajaran klinik tersebut perkembangan kemampuan kognitif dan afektif mahasiswa dipengaruhi oleh keberadaan pembimbing praktek, proses bimbingan yang diberikan, dan sarana penunjang pembelajaran praktika. Dalam proses pembelajaran praktik asuhan kehamilan di Prodi D 3 Kebidanan Undiksha, dosen pembimbing telah berupaya untuk melakukan proses bimbingan sesuai dengan kaidah-kaidah pembelajaran praktika, dimana mahasiswa diajarkan langkah-langkah pelaksanaan asuhan kehamilan dengan menggunakan metode pendekatan manajemen kebidanan dan penuntun belajar atau daftar tilik. Setelah diberikan pembelajaran secara teoritik, dosen pembimbing melanjutkan dengan mendemonstrasikan tehnik pelaksanaan asuhan kehamilan kepada mahasiswa. Demonstrasi yang dilakukan dengan menggunakan panthoom sebagai model, dimaksudkan untuk memberikan gambaran kepada mahasiswa mengenai tehnik pelaksanaan asuhan kebidanan pada ibu hamil. Lefrancois (dalam Alit, 2001) menyatakan bahwa keuntungan terbesar dari proses pembelajaran dengan menggunakan model adalah dapat memberikan serangkaian tindakan perilaku yang lengkap kepada peserta didik. Setelah demonstrasi oleh dosen pembimbing, kemudian dilanjutkan dengan demonstrasi yang dilakukan mahasiswa sesuai prosedur dan tehnik yang diajarkan. Selanjutnya mahasiswa diberi kesempatan untuk melakukan latihan mandiri asuhan kehamilan di laboratorium klinik kampus, sebelum mahasiswa di evaluasi. Evaluasi dilakukan untuk mendapatkan gambaran mengenai seberapa besar tingkat pemahaman mahasiswa terhadap bimbingan yang diberikan, sehingga berdasarkan hasil evaluasi tersebut mahasiswa dapat dinyatakan telah mampu dan siap untuk diterjunkan ke lahan praktik baik di rumah sakit maupun pusat pelayanan kesehatan masyarakat.

Hasil perhitungan regresi sederhana $Y$ dan $X_{1}$ ditemukan persamaan : $\hat{Y}=60,059+0,151 X_{1}$ dengan $F_{\text {reg }}=18,391$ lebih besar dari $F_{\text {tabel }}=3,96$ pada $\alpha=0,05$ adalah signifikan dan linier. Kuat hubungan antara bimbingan praktik $\left(\mathrm{X}_{1}\right)$ dengan pencapaian kompetensi keterampilan asuhan kehamilan $(\mathrm{Y})$ dihitung dengan perhitungan hubunagn product moment. Berdasarkan hasil analisis diperoleh $r_{\text {hitung }}=0,386$ lebih besar dari $r_{\text {tabel }}=0,220$ pada $\alpha=0,05$ adalah signifikan, dengan $r^{2}=0,149$.

Berdasarkan analisis tersebut dapat disimpulkan bahwa terdapat hubungan yang positif dan signifikan antara bimbingan praktik dengan pencapaian kompetensi keterampilan mahasiswa Prodi D 3 Kebidanan Undiksha, dengan kontribusi 22,0 \%. Dengan kata lain bahwa makin baik bimbingan praktik yang diberikan maka akan semakin baik pula pencapaian kompetensi keterampilan. Variabel bimbingan praktik ini memberikan sumbangan efektif (SE) sebesar 7,50 \% terhadap pencapaian kompetensi keterampilan asuhan kehamilan mahasiswa Prodi D 3 Kebidanan Undiksha.

Pencapaian kompetensi keterampilan mahasiswa dalam melaksanakan asuhan kehamilan tidak lepas dari bimbingan yang diberikan selama proses pembelajaran. Melalui bimbingan keterampilan praktek untuk mencapai kompetensi, mahasiswa dapat menerapkan teori-teori yang didapat selama pembelajaran teoritik ke dalam tindakan klinis yang tepat sebagai persiapan dalam menghadapi situasi nyata di lapangan kerja. Hal ini sejalan dengan pendapat Nursalam (2002) yang menjelaskan bahwa bimbingan praktek merupakan upaya untuk menumbuhkan kemampuan professional (intelektual, teknikal dan interpersonal) peserta didik melalui upaya integrasi berbagai konsep, teori dan prinsip keperawatan dalam rangka memenuhi kebutuhan dasar klien secara komprehensif. Bimbingan praktek membantu peserta didik mencapai tujuan yang ditetapkan dalam pembelajaran klinik melalui proses peningkatan kemampuan intelektual, teknikal dan interpersonal yang dilandasi etika profesi.

Meskipun hasil deskriptif yang diperoleh dari data bimbingan praktek hanya berada pada katagori cukup, namun hal tersebut juga memiliki kontribusi dalam meningkatkan kemampuan/kompetensi mahasiswa dalam pelaksanaan asuhan kebidanan termasuk asuhan kehamilan. Karena tanpa bimbingan praktek, pemahaman mahasiswa mengenai asuhan kebidanan termasuk asuhan kehamilan akan sangat rendah dan hal itu akan berdampak pada kemampuan/ kompetensi mereka dalam melaksanakan asuhan kehamilan kepada klien.

\section{Simpulan dan saran}

Berdasarkan hasil penelitian yang telah diuraikan pada Bab 4, berikut ini akan disajikan kesimpulan mengenai hubungan antara Bimbingan Praktik (X) dengan Pencapaian Kompetensi Keterampilan Asuhan 
Kehamilan (Y) mahasiswa Prodi D 3 Kebidanan Undiksha adalah sebagai berikut : Ada hubungan yang signifikan antara Bimbingan Praktik (X) dengan Pencapaian Kompetensi Keterampilan Asuhan Kehamilan (Y), dengan kontribusi sebesar 14,9\% dan sumbangan efektif sebesar 7,50\%. Berdasarkan hasil penelitian ini dapat disimpulkan bahwa Bimbingan Praktik terhubung secara signifikan terhadap Pencapaian Kompetensi Keterampilan Asuhan Kehamilan mahasiswa Prodi D 3 Kebidanan Undiksha, baik secara terpisah maupun simultan. Dengan demikian variabel Bimbingan Praktik tersebut dapat dijadikan prediktor tingkat kecenderungan Pencapaian Kompetensi Keterampilan Asuhan Kehamilan mahasiswa Prodi D 3 Kebidanan Undiksha.

Bertitik tolak dari temuan pada penelitian ini maka dapat diberikan saran-saran sebagai berikut : 1) Kepada Pemegang Kebijakan, Untuk dapat meningkatkan kompetensi keterampilan mahasiswa, dibutuhkan sarana dan peralatan yang memadai untuk menunjang proses belajar praktek sehingga diharapkan agar pemegang kebijakan pada Prodi D 3 Kebidanan Undiksha dapat lebih memperhatikan kebutuhan-kebutuhan tersebut dengan jalan : (1) memberikan kesempatan kepada para dosen pembimbing di mata kuliah-mata kuliah yang menunjang peningkatan kompetensi keterampilan asuhan kebidanan untuk mengikuti pelatihan-pelatihan yang berkaitan dengan praktik kebidanan; (2) menugaskan dosen pembimbing dari institusi pendidikan untuk melakukan praktek klinik bersama-sama (pendampingan praktek) agar dapat mamantau secara lebih intensif kemajuan praktek mahasiswa serta membantu mahasiswa untuk meningkatkan kemampuan keterampilannya dalam melaksanakan asuhan kebidanan pada tatanan nyata, dan juga untuk menyamakan persepsi tentang proses bimbingan dengan para pembimbing di lahan praktek; dan (3) melakukan pengadaan sarana dan peralatan yang dibutuhkan untuk proses belajar praktik guna menunjang upaya peningkatan kompetensi keterampilan mahasiswa dalam melaksanakan asuhan kebidanan.2) Kepada para Pembimbing Praktik, untuk meningkatkan kompetensi keterampilan dan kemampuan mahasiswa dalam melaksanakan asuhan kebidanan secara komprehensif maka diharapkan kepada para pembimbing praktik baik di kampus maupun di lahan praktik untuk lebih meningkatkan kualitas bimbingan, dengan jalan : (1) lebih sering memberikan kesempatan kepada mahasiswa mengembangkan strategi saat implementasi asuhan kebidanan; (2) memberikan umpan balik kepada mahasiswa terhadap hasil belajar yang diperolehnya; (3) memberikan pembekalan awal dan akhir praktik di ruangan saat pelaksanaan praktik asuhan kebidanan; (4) mendorong tumbuhnya inisiatif mandiri dari mahasiswa; dan (5) meningkatkan motivasi dan konsep diri mahasiswa dengan menunjukkan sikap percaya dan menghargai kemampuan mahasiswa dalam aktivitas dan kreativitas belajarnya. 3) Kepada Mahasiswa, sebagai calon bidan profesional, mahasiswa diharapkan untuk lebih giat memperdalam ilmu dan keterampilan agar dapat lebih kompeten dalam melaksanakan asuhan kebidanan dengan jalan: (1) lebih sering melakukan asuhan kebidanan termasuk asuhan kehamilan secara komprehensif dengan tetap berpedoman pada daftar tilik yang diberikan; (2) meningkatkan motivasi diri untuk menjadi seorang bidan yang profesional dan berkompeten, (3) mempersiapkan diri secara matang dengan pengetahuan dan keterampilan sebelum pelaksanaan praktik klinik; dan (4) meningkatkan rasa percaya diri terhadap kemampuan mencapai kompetensi yang diharapkan.

\section{Daftar Rujukan}

Alit, Ni Ketut. Praktek Belajar Klinik. Modul pembelajaran yang tidak dipublikasikan. PSIK - FK Unair Surabaya. 2001

Azwar Azrul. Pengantar Administrasi Kesehatan. Jakarta : Binarupa Aksara. 1996

Cochran, WG. Sampling Techniques. New Delhi : Eastern Private Limited. 1974

Cohen, L. Educational Research in Classroom and Schools : a Manual of Materials and Method. London : Harver \& Row Publisher. 1978

Depkes RI. Kurikulum Pendidikan Diploma III D 3 Kebidanan Bagi Lulusan Bidan. Jakarta. Depkes RI. 2002

Djamariah, Syaiful Bahri dkk. Strategi Belajar Mengajar. Jakarta : Rineka Cipta. 2002

Grant, A.B dan Massey, VH. Nursing Leadership, Management and Research. Pennsylvania : Springhouse. 1999

Hamalik, Oemar. Pendidikan Guru Berdasarkan Pendekatan Kompetensi. Jakarta : PT. Bumi Aksara. 2003 
Hamalik, Oemar. Kurikulum dan Pembelajaran. Jakarta : PT. Bumi Aksara. 2005

Hamzah B. Uno, et.al. Pengembangan Instrumen Untuk Penelitian. Jakarta : Dilema Press. 2001

Hamzah B. Uno, et.al. Teori Motivasi dan Pengukurannya. Jakarta : PT. Bumi Aksara. 2007

.http://wangmuba.com/2009/03/07/aspek-aspekkonsepdiri Diakses tanggal 18/07/2009. Psikologi Kepribadian

Hurlock, Elizabeth B. Child Development. Sixth Edition. Penerjemah : Meitasari Tjandra. Jakarta : Erlangga. 1978

Joni, T. Raka. Strategi Belajar Mengajar. Jakarta. P3G. 1980

Kartini Kartono. Pemimpin dan Kepemimpinan. Jakarta : PT. Raja Grafindo Persada. 2004

Komariah, Aan dan Cepi Triatna. Visionary Leadership Menuju Sekolah Efektif. Jakarta : PT. Bumi Aksara. 2006

Koyan, I Wayan. Statistika Terapan (Tehnik Analisis Data Kuantitatif) Buku Ajar. Prodi PEP Program Pascasarjana Undiksha. Undiksha. 2007

Margono, S. Metodologi Penelitian Pendidikan. Jakarta : Rineka Cipta. 2004

McClelland,D.C., Atkinson, J.W., Clark, R.A., and Lowell, E.L. The Achievement Motive. New York : Irvington Publishers Inc. 1976

Menkes RI. SK Menteri Kesehatan Republik Indonesia No. 900/Menkes/SK/VII/2002 Tentang Registrasi dan Praktek Bidan. Jakarta : Depkes RI. 2002

Nasution, S. Kurikulum dan Pengajaran. Bandung. Bina Aksara. 1989

Notoatmodjo Soekidjo. Promosi Kesehatan Dan Ilmu Perilaku. Jakarta : Rineka Cipta. 2007

Nursalam.. Manajemen Keperawatan : Aplikasi dalam Praktik Keperawatan Profesional. Edisi Pertama. Jakarta : Salemba Medika. 2002

Prawirorahardjo,S. Buku Acuan Nasional : Pelayanan Kesehatan Maternal dan Neonatal. Jakarta. Yayasan Bina Pustaka. 2002

Pusat Pengembangan Keperawatan Carolus (PPKC)/Publik. Asuhan D 3 Kebidanan dalam Proses Manajemen D 3 Kebidanan. Jakarta. Pelatihan Manajemen Asuhan D 3 Kebidanan. Tidak dipublikasikan. 2002

Pusdiknakes Depkes RI. Pedoman Penilaian Pencapaian Kompetensi Pendidikan Tenaga Kesehatan. Jakarta : Badan Pengembangan dan Pemberdayaan SDM Kesehatan Depkes. 2005

Saiful, Bahri. Strategi Belajar Mengajar. Jakarta : Rineka Cipta. 2002

Sanjaya, Wina. Pembelajaran dalam Implementasi Kurikulum Berbasis Kompetensi. Jakarta. Kencana, Prenada Media Group. 2005

Sanjaya, Wina. Strategi Pembelajaran Berorientasi Standar Proses Pendidikan. Jakarta. Kencana. 2007

Sugiyono. Memahami Penelitian Kualitatif. Bandung : CV. Alfabeta. 2007

Suliswati, dkk. Konsep Dasar Keperawatan Kesehatan Jiwa. Jakarta : Penerbit Buku Kedokteran EGC. 2005.

Varney, H., Kriebs, J.M., \& Gegir, C.L.. Buku Saku Bidan. Jakarta. EGC. 2002 